\title{
Pretreatment of Stabilized Landfill Leachate Using Ozone
}

\author{
Anna Kwarciak-Kozłowska \\ 1 Institute of Environmental Engineering, Czestochowa University of Technology, Czestochowa, Poland, \\ e-mail: akwarciak@is.pcz.czest.pl
}

\begin{abstract}
The paper presents the possibility of using the ozonation process in landfill leachate pretreatment. The study was conducted in three stages. In the first stage, the landfill leachate was subjected only to the ozone, with the dose varying from $10 \mathrm{mg} / \mathrm{dm}^{3}$ to $40 \mathrm{mg} / \mathrm{dm}^{3}$. As part of this stage of research, the effect of changes in the $\mathrm{pH}$ of wastewater undergoing the process of ozonation on the efficiency of TOC removal was examined. For all the tested $\mathrm{pH}$ values $(\mathrm{pH}=3.5, \mathrm{pH}=7 \mathrm{pH}=8.5 \mathrm{pH}=10)$, the TOC removal rate constant $\left(\mathrm{k}_{\text {Rowo }}\right)$ during ozonization was determined. In the second stage of the study, the ozonation process was facilitated by UV radiation. Additionally in this stage, the rate of generation of $\mathrm{OH} \bullet$ radicals was accelerated by the addition of hydrogen peroxide to the reactor. The COD: $\mathrm{H}_{2} \mathrm{O}_{2}$ ratio by weight was 1:2.5, 1:5 and 1:10 and 1:20. In the last stage of the study, we attempted to assist the ozonation process using ultrasonic field. The employed vibration amplitude amounted to $25 \mu \mathrm{m}$ and sonication time equalled 300 seconds. It was found that the ozonation process is the most effective at alkaline $\mathrm{pH}(8.5)$. The TOC removal efficiency was $37 \%\left(346 \mathrm{mg} / \mathrm{dm}^{3}\right)$ after 60 minutes of ozonation. The best results of pollutants oxidation measured as COD and TOC removal were observed when the dose of ozone was $20 \mathrm{mg} / \mathrm{dm}^{3}$. The combination of sonication and ozonation has resulted in a reduction of COD and TOC values by $370 \mathrm{mg} / \mathrm{dm}^{3}$ and $126 \mathrm{mg} / \mathrm{dm}^{3}$, respectively, in comparison to the ozonation process alone. It was found that the most effective process in landfill leachate treatment is the combination of ozonation with hydrogen peroxide addition (COD: $\mathrm{H}_{2} \mathrm{O}_{2}=1: 10$ ). The COD, TOC and BOD values were $65 \%, 62 \%$ and $36 \%$ lower, respectively, in comparison to ozonation process conducted alone.
\end{abstract}

Keywords: landfill leachate, ozonation, hydrogen peroxide, ultrasonic field, advanced oxidation process

\section{INTRODUCTION}

The term 'leachate' means the water generated in landfills due to the seepage of rainwater through the bed. They elute organic and mineral compounds resulting from the biological and physicochemical changes from the landfills waste. Although many methods may be applied, the most appropriate leachate treatment choice will depend on its features, technical applicability, cost effectiveness, and other factors related to the quality requirements of the effluents. The leachate produced in mature landfills contains significant amounts of humic acids having a very stable structure which is difficult to breach by bacteria. Therefore, the purification efficiency by the biological method of the activated sludge is not very high [Kurniwana and Wai-hung 2006;
Kwarciak-Kozłowska and Sławik-Dembiczak 2016]. Advanced oxidation processes (AOP) represent relatively new methods while their mechanism is based on the generation of free hydroxyl radicals. AOP encompasses ozonation which is a treatment based on the high oxidant power of ozone that can be used to decompose large organic molecules into smaller and less complex ones occurring at normal pressure and temperature being, hence, industrially interesting [Amaral-Silva et al. 2016]. Ozone belongs to very strong oxidants and therefore starts reactions with many organic and inorganic compounds. It is selective in direct reactions with organic compounds; Conversely, hydroxyl radicals are usually non-selective with respect to these compounds [Zarzycki 2002]. Ozonation alters the molecular structure of refractory organic compounds pres- 
ent in the leachate, turning them into compounds that are easily assimilated biologically. The ozone processes can be made more effective for example at high $\mathrm{pH}\left(\mathrm{O}_{3} / \mathrm{OH}^{-}\right)$and by the addition of hydrogen peroxide $\left(\mathrm{O}_{3} / \mathrm{H}_{2} \mathrm{O}_{2}\right)$. These systems (Peroxone process) favour the production of hydroxyl radicals $(\bullet \mathrm{OH})$, which are highly reactive species. $\mathrm{OH}^{-}$and $\mathrm{H}_{2} \mathrm{O}_{2}$ initiate a series of radical reactions that enhance the ozone decomposition to yield • OH [Bila et al. 2005; Tizaoui et al. 2007, Catalkaya and Kargi 2007; Hansen et al. 2016; Liu et al. 2015; Zarzycki 2002]. Furthermore, the effect of the ultrasonic wave is connected with the stimulation of the cavitation phenomenon [Suslick 1989]. The energy released during the implosion of the cavity bubbles is able to initiate a thermal decomposition of water particles using the hydroxyl radicals [Barbusiński 2013; Cesaro et al. 2013; Xu et al. 2005].

As a result, this research was carried out in order to investigate the treatment of landfill leachate using ozone-bases processes (i.e. $\mathrm{O}_{3}$ alone, $\mathrm{O}_{3} / \mathrm{H}_{2} \mathrm{O}_{2}$ and $\left.\mathrm{O}_{3} / \mathrm{US}\right)$. This study investigated the effects of different operating parameters such as, $\mathrm{H}_{2} \mathrm{O}_{2}$ concentration (COD: $\mathrm{H}_{2} \mathrm{O}_{2}$ was $1: 2.5,1: 5$ and $1: 10$ and $1: 20$ ), dose of ozone $\left(10-40 \mathrm{mg} / \mathrm{dm}^{3}\right)$ and sonication process (ampitude $25 \mu \mathrm{m}$, sonication time 300 ).

\section{MATERIALS AND METHODS}

The leachate was derived from the regional municipal waste landfill in Silesian Province (Poland). The leachate was characterised by the $\mathrm{pH}$ of 7.89 and light brown colour. The COD value was $2885 \mathrm{mg} / \mathrm{dm}^{3}$ on average and BOD was under $190 \mathrm{mg} / \mathrm{dm}^{3}$. The BOD/COD ratio was at a low level (0.06) that indicated low biodegradability. The amount of TOC was $550 \mathrm{mg} / \mathrm{dm}^{3}$.

The process of landfill leachate ozonation was performed in a cylindrical glass reactor with the diameter of $10 \mathrm{~cm}$ and active volume of $4 \mathrm{dm}^{3}$. The positive pressure system for supplying of air-ozone mixture to the reaction chamber was used. Fine-bubble aeration was performed using the diffuser located at the reactor bottom. Ozone was generated from oxygen using the OZOMATIC LAB 802 ozonizer, with the range of airozone mixture production ranging from 0.1 to $1 \mathrm{dm}^{3} / \mathrm{min}$. The gas flow rates were adjusted using the RO6 RP T96193 rotameter ( $\max 45 \mathrm{dm}^{3} / \mathrm{h}$ ). The measurement of the ozone content at the out- let from the reaction chamber was conducted using the Dreschel washing bottle with the absorption solution connected with the valve located at its top [Kwarciak-Kozłowska et al. 2016].

The sonication of the landfill leachate was performed using the Sonics vibro cell ultrasonic disintegrator which generated the ultrasonic wave with vibration frequency $40 \mathrm{kHz}$. The power adjustment in the device was possible through the digital adjustment of the percentage of maximal amplitude of the sonotrode $(\max 123 \mu \mathrm{m})$ [Kwarciak-Kozłowska and Sławik-Dembiczak 2016].

The examinations were performed at three stages. At the first stage, the leachate was exposed to the effect of ozone, with the doses changing in the range from $10 \mathrm{mg} / \mathrm{dm}^{3}$ to $40 \mathrm{mg} / \mathrm{dm}^{3}$. The ozone efficiency was controlled by the adjustment of the generator efficiency (from 5\% to $100 \%$ ) to the specific gas flow rate (from $10 \mathrm{dm}^{3} / \mathrm{h}$ to 40 $\mathrm{dm}^{3} / \mathrm{h}$ ). At this stage, the effect of $\mathrm{pH}$ of the liquors subjected to ozonation on the degree and rate of TOC removal was determined.

At the second stage of the examinations, the rate of generation of $\mathrm{OH} \bullet$ radicals in the ozonation process was accelerated by adding hydrogen peroxide to the reaction chamber. Its amount was increased in the geometrical progress by $\mathrm{q}=2$, at initial amount of 1:2.5 (ChZT: $\left.\mathrm{H}_{2} \mathrm{O}_{2}\right)$.

At the last stage, the ozonation process was combined with the ultrasonic field. The ultrasonic field parameters such as sonication time $(300 \mathrm{sec})$ and vibration amplitude $(25 \mu \mathrm{m})$ used at this stage were the most advantageous values determined from the previous examinations concerning demonstration of the effect of the ultrasonic field on the change of the biodegradability of landfill leachate [Kwarciak-Kozłowska and Sławik-Dembiczak 2016]. The efficiency of the unit processes used in the study was controlled based on the changes in the levels of COD, TOC and BOD. The study design and methodology of determination are presented in Figure 1.

\section{RESULTS AND DISCUSSION}

Effect of $\mathrm{pH}$ of landfill leachate and ozone doze on the degree of ozonation of contaminants (stages 1)

The first step of the experiment examined the effect of the initial $\mathrm{pH}$ value of the landfill leachate subjected to ozonation on the TOC removal 


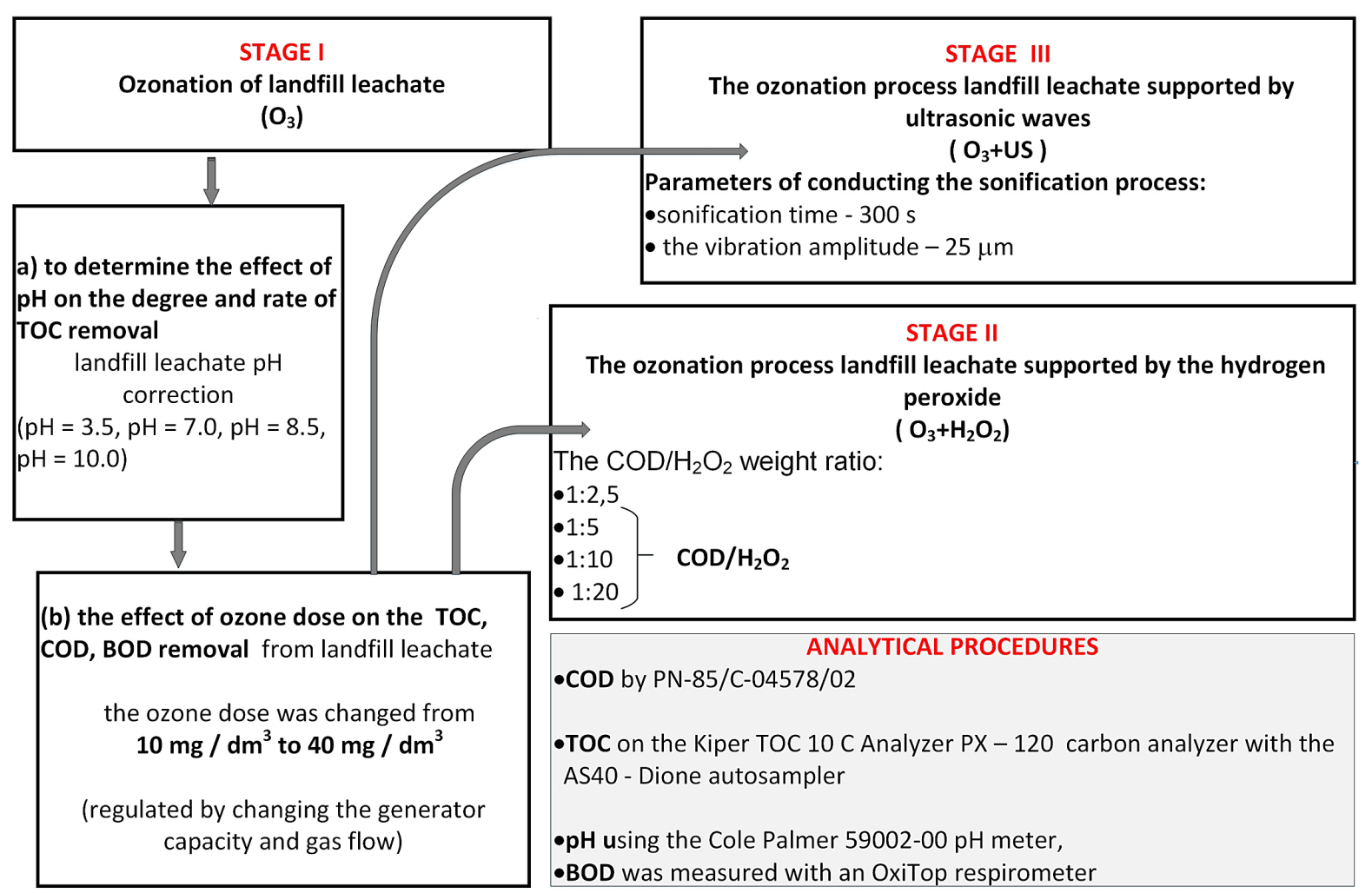

Figure 1. The scheme of treatment the landfill leachate in ozonation process

rate. This stage was performed at a constant ozone dose of $10 \mathrm{mg} / \mathrm{dm}^{3}$. The ozonation was performed for the initially acidified liquor $(\mathrm{pH} 3.5)$ and the TOC removal rate ranged from $7 \%$ (5 min of the process) to $13 \%$ (60 $\mathrm{min}$ of the process).

After 60 minutes of the process, the TOC value reduced from $550 \mathrm{mg} / \mathrm{dm}^{3}$ to $451 \mathrm{mg} / \mathrm{dm}^{3}$. It was found that the landfill leachate ozonation process occurs most effectively when their $\mathrm{pH}$ is initially at the level of 8.5. After 60 minutes, the TOC removal rate reached $37 \%\left(346 \mathrm{mg} / \mathrm{dm}^{3}\right)$. Further alkalization of raw leachate to $\mathrm{pH}=10$ resulted in a slight decline in the removal rate to $25 \%\left(412 \mathrm{mg} / \mathrm{dm}^{3}\right)$. Similar effects were observed when the landfill leachate reaction was neutral. The TOC removal rate reached 28\% (396 $\mathrm{mg} / \mathrm{dm}^{3}$ ). These changes are illustrated in Fig. 2a. At this stage, the changes in the TOC removal rate were also analysed. For a specific time range (from $5 \mathrm{~min}$ to $30 \mathrm{~min}$ ), the TOC degradation process was the first order reaction which then was transformed into a quasi-static reaction (Fig. $2 b)$. Assuming that the decomposition of organic compounds determined as TOC in the ozonation process was the first order reaction, a reaction rate constant was determined based on the LangmuirHinshelwood formula [Kudlek et al. 2017].
The analysis of the results obtained for constant TOC degradation rates revealed that the oxidation of organic compounds contained in landfill leachate occurs much faster in the first minutes of the process. The value of $\mathrm{k}_{\mathrm{rTOC}}$ for wastewater with $\mathrm{pH}=3.5, \mathrm{pH}=7.0, \mathrm{pH}=8.5$ and $\mathrm{pH}=10$ in the 5 th minute of the process was $0.014 \mathrm{~min}^{-1}$, $0.027 \mathrm{~min}^{-1}, 0.054 \mathrm{~min}^{-1}$ and $0.023 \mathrm{~min}^{-1}$. In the 60th minute of the process, the value of these coefficients were substantially reduced and amounted to $0.0039 \mathrm{~min}^{-1}(\mathrm{pH}=3.5), 0.0066 \mathrm{~min}^{-1}(\mathrm{pH}=7.0)$, $0.0092 \mathrm{~min}^{-1}(\mathrm{pH}=8.5)$ and $0.0057 \mathrm{~min}^{-1}(\mathrm{pH}=10)$.

The second step of this stage of the examinations was to evaluate the effect of the contaminant removal from the landfill leachate on the amount of the ozone supplied to the reaction chamber. The ozone dose was changed from $10 \mathrm{mg} / \mathrm{dm}^{3}$ to $40 \mathrm{mg} / \mathrm{dm}^{3}$. The COD and TOC of the raw landfill leachate were $2885 \mathrm{mg} / \mathrm{dm}^{3}$ and $550 \mathrm{mg} / \mathrm{dm}^{3}$. The worst effects of ozonation of contaminants determined as COD and TOC were observed when the lowest ozone dose was used. The 60 -minute period of ozonation contributed to the removal of contaminants denoted as COD and TOC by $37 \%\left(220 \mathrm{mg} / \mathrm{dm}^{3}\right)$ and $42 \%\left(1673 \mathrm{mg} / \mathrm{dm}^{3}\right)$. The double ozone dose $\left(20 \mathrm{mg} / \mathrm{dm}^{3}\right)$ resulted in the increase in the removal rates for TOC (by 19\%) 

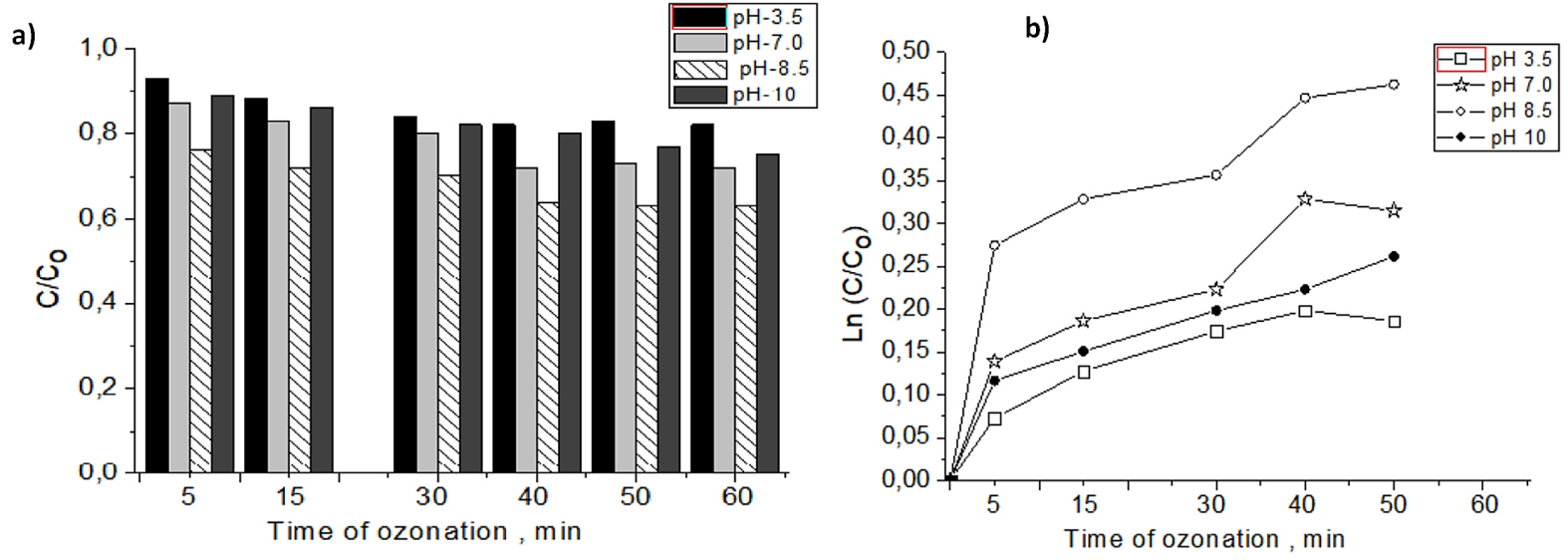

Figure 2. Effect of $\mathrm{pH}$ on the ozonation and removal of TOC- $\mathrm{C} / \mathrm{Co}$ (a) and $\mathrm{lnC} / \mathrm{Co}$ (b)

and COD (by 18\%). Further increase of the ozone dose resulted in the reduction in the effectiveness of contamination oxidation. The rate of COD removal from landfill leachate after an hour process of ozonation at the ozone dose of $30 \mathrm{mg} / \mathrm{dm}^{3}$ was $54 \%$, whereas the COD value for treated leachate was $1327 \mathrm{mg} / \mathrm{dm}^{3}$. With this ozone dose, the rate of TOC removal was $50 \%$, whereas its content in the treated landfill leachate reduced to the level of $275 \mathrm{mg} / \mathrm{dm}^{3}$. It was found that for all the used doses of ozone, the elongation of the time of the process to over 45 minutes did not lead to an increase in the oxidation of the contaminants contained in the landfill leachate. These changes are illustrated in Figures 3 and 4.

After determination of the most advantageous ozone dose $\left(20 \mathrm{mg} / \mathrm{dm}^{3}\right)$ the BOD was evaluated during a 60 minute process of landfill leachate oxidation. After the 5th minute of the ozonation process, the value of BOD reduced from the level of $190 \mathrm{mg} / \mathrm{dm}^{3}$ to $135 \mathrm{mg} / \mathrm{dm}^{3}$. Extension of the ozonation time to 15 minutes resulted in

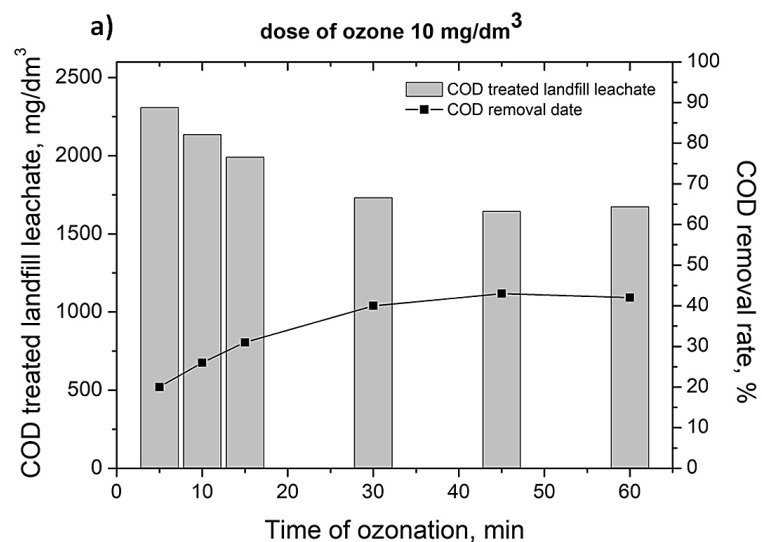

b)
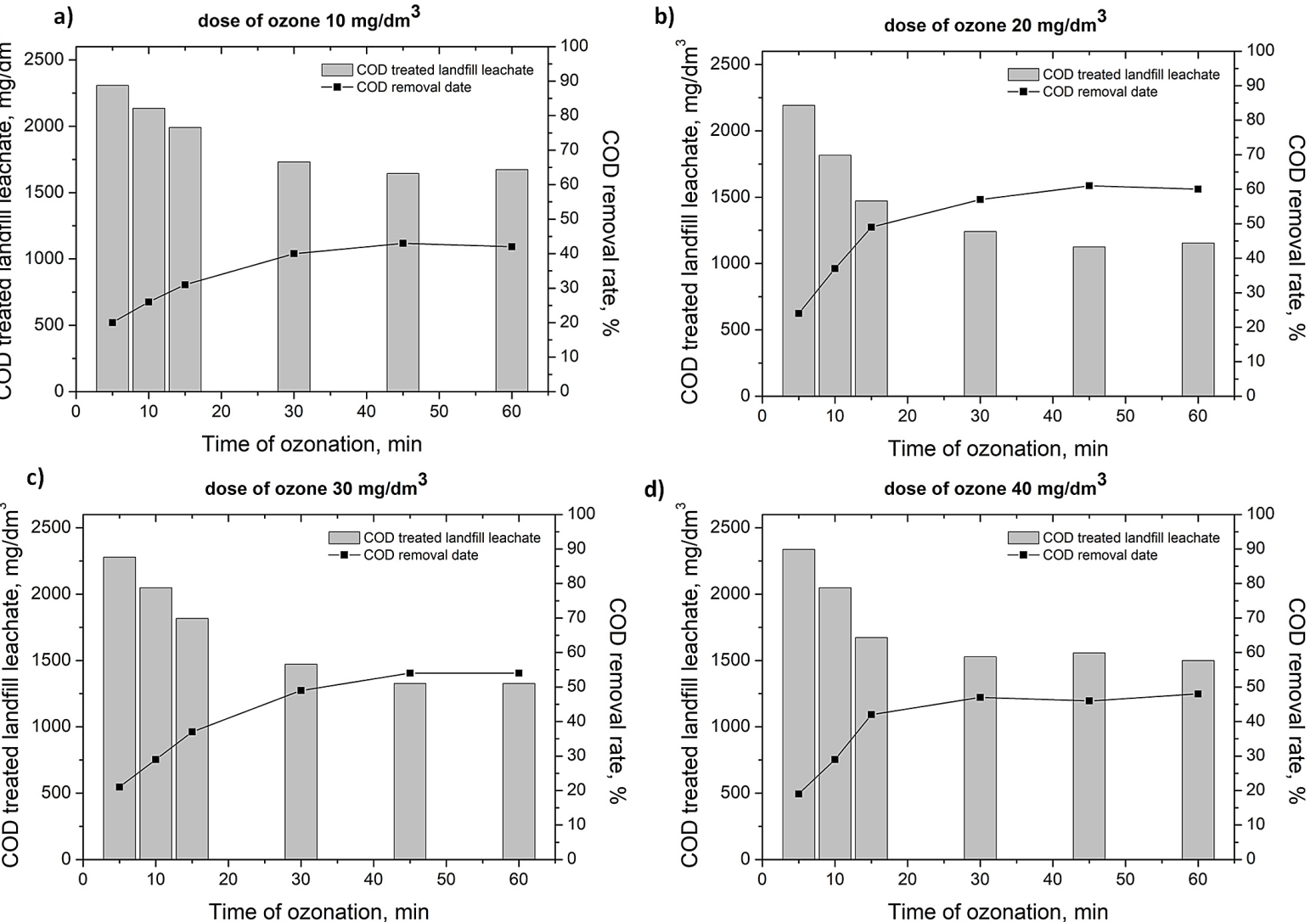

Figure 3. The effect of the ozone dose on the COD removal rate 

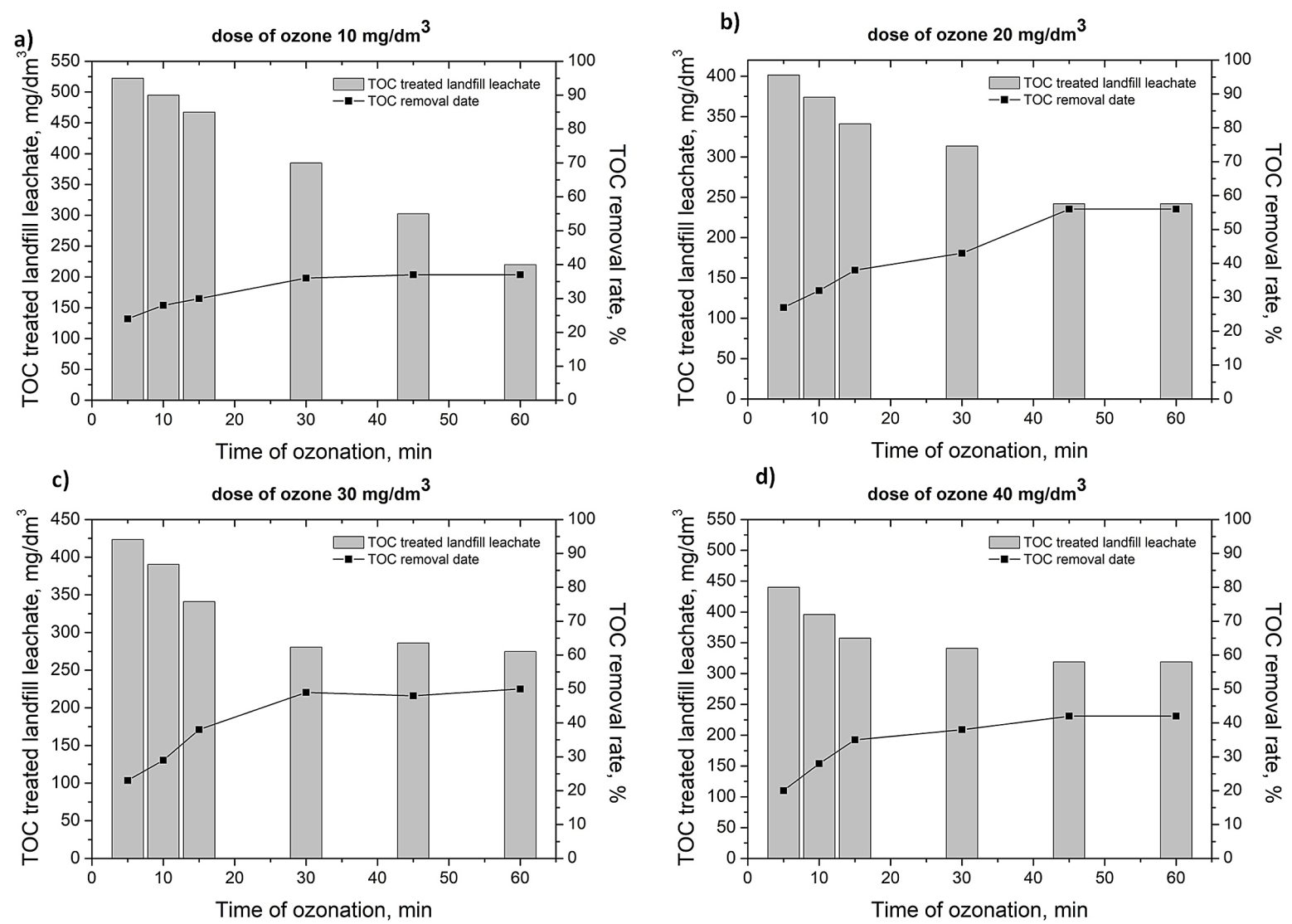

Figure 4. The effect of the ozone dose on the TOC removal rate

the increase in its removal rate by another $30 \%$, i.e. to the level of $59 \%\left(78 \mathrm{mg} / \mathrm{dm}^{3}\right)$. After 30 minutes and 60 minutes of ozonation, the value of the BOD did not change and was at a similar level of $42 \mathrm{mg} / \mathrm{dm}^{3}$.

Leszczyński et al. [2016] conducted research on the use of the ozonization process for stabilized landfill leachate treatment. The average values of its main parameters were: $\mathrm{pH}$ 8.32, COD $870 \mathrm{mg} / \mathrm{dm}^{3}$, BOD $90 \mathrm{mg} / \mathrm{dm}^{3}, \mathrm{NH}_{4}{ }^{+} 136.2 \mathrm{mg} /$ $\mathrm{dm}^{3}$, UV254 absorbance 0.312 and turbidity 14 NTU. The ozone dosages were used in the range of 115.5 to $808.5 \mathrm{mg} / \mathrm{dm}^{3}$ of the leachate. The maximum COD, colour and UV254 absorbance adjustment were $37.3 \% ; 81.6 \%$ and $59.2 \%$, respectively, by applying a high ozone dose of $808.5 \mathrm{mg} / \mathrm{dm}^{3}$. After oxidation, the ratio of BOD/COD was increased from 0.1 up to 0.23 [Leszczyński et al. 2016].

\section{Treatment of landfill leachate using the system of $\mathrm{O}_{3}+\mathrm{H}_{2} \mathrm{O}_{2}$ (stages 2)}

At two next stages of the examinations, the attempts were made to intensify the ozonation process by its combination with another unit pro- cess. In the first step, the ozonation process was supported by the effect of hydrogen peroxide. Four doses were used in the experiment, with the mass ratio of $\mathrm{H}_{2} \mathrm{O}_{2}$ to COD of raw landfill leachate of 2.5:1, 5:1, 10:1 and 20:1. The ozone dose was maintained at the level of $20 \mathrm{mg} / \mathrm{dm}^{3}$.

It was found that during the process that combines ozonation with hydrogen peroxide (system $\mathrm{O}_{3}+\mathrm{H}_{2} \mathrm{O}_{2}$ ) at the lowest dose (COD: $\mathrm{H}_{2} \mathrm{O}_{2}=1: 2.5$ ), the effectiveness of oxidation of the contaminants denoted as COD and TOC was the lowest. After 5 minutes of the process, the COD removal rate was $46 \%$ and its extension to 60 minutes caused an increase in the efficiency of oxidation of contaminants to $72 \%$ (COD of the treated landfill leachate: $807 \mathrm{mg} / \mathrm{dm}^{3}$ ). With this dose of the hydrogen peroxide, the TOC removal rate following an hour of ozonation was $70 \%$ and its value in the raw landfill leachate was reduced from $550 \mathrm{mg} / \mathrm{dm}^{3}$ to $165 \mathrm{mg} / \mathrm{dm}^{3}$.

The most effective process supported by $\mathrm{H}_{2} \mathrm{O}_{2}$ occurred when the ratio of COD: $\mathrm{H}_{2} \mathrm{O}_{2}$ was 1:10. After 45 minutes and 60 minutes of the combined process $\left(\mathrm{O}_{3}+\mathrm{H}_{2} \mathrm{O}_{2}\right)$, the COD value of the treated landfill leachate was similar, with $375 \mathrm{mg} / \mathrm{dm}^{3}$ $(87 \%)$ and $403 \mathrm{mg} / \mathrm{dm}^{3}(86 \%)$. The degree of 
TOC removal after 60 minutes of the treatment process reached the level of $83 \%$, and its value in the treated leachate was $93 \mathrm{mg} / \mathrm{dm}^{3}$.

Figure 5 illustrates the changes in TOC (a) and COD (b) of the treated landfill leachate depending on the dose of hydrogen peroxide.

The research confirms that the support of ozone treatment with $\mathrm{H}_{2} \mathrm{O}_{2}$ results in an increase in the efficiency of stabilized leachates treatment [Amaral-Silva et al. 2016; Tizaoui et al. 2007]. In the Amaral-Silva studies, the highest organic load removal and biodegradability improvement was observed with the $\mathrm{O}_{3} / \mathrm{H}_{2} \mathrm{O}_{2}$ process using $4 \mathrm{~g} / \mathrm{dm}^{3}$ $\mathrm{H}_{2} \mathrm{O}_{2}$. This system was able to eliminate $45 \%$ of the $\mathrm{COD}, 89 \%$ of the leachate $\mathrm{BOD} / \mathrm{COD}$ ratio from 0.05 to 0.29 permitting the treated wastewater for the local sewage collector [Amaral-Silva et al. 2016]. Tizaoui et al. 2007 found that the ozone efficiency was almost doubled when combined with hydrogen peroxide at $2 \mathrm{~g} / \mathrm{dm}^{3}$ and higher. $\mathrm{H}_{2} \mathrm{O}_{2}$ gave lower performances. Enhancement in the leachate biodegradability from about 0.1 to about 0.7 was achieved by the $\mathrm{O}_{3} / \mathrm{H}_{2} \mathrm{O}_{2}$ system [Tizaoui et al.2007].

\section{Treatment of landfill leachate using the system of $\mathrm{O}_{3}+\mathrm{US}$ (stage 3 )}

The last stage of the experiment was aimed at examining the effect of ultrasonic waves (US) on the change in the efficiency of treatment of landfill leachate subjected to ozonation. It was assumed that the free radicals of $\mathrm{H}^{*}, \mathrm{HO}^{*}, \mathrm{HOO}$, ozone, and hydrogen peroxide generated through the effect of ultrasonic waves should contribute to the increased degree of oxidation and/or destabilization of the organic substance compared to the independently performed ozonation process.
The examination performed by the authors previously demonstrated that the most effective sonication process occurs at the vibration amplitude of $25 \mu \mathrm{m}$ and reaction time of 300 seconds. The process of liquor sonication substantially affected the generation and release of aliphatic compounds. Furthermore, a substantial number of compounds with the $-\mathrm{OH}$ functional group that can originate from alcohols and carboxyl acids was observed. [Kwarciak-Kozłowska and Sławik-Dembiczak 2016]. The value of acoustic energy supplied to the landfill leachate sample for such parameters of the ultrasonic field was on average $32459 \mathrm{~J}$. The changes caused in liquors are connected with e.g. cavitation. It was found that with these parameters of the ultrasonic field, the intensity of the ultrasound wave was higher than the theoretical threshold of cavitation $\left(1.0 \mathrm{~W} / \mathrm{cm}^{2}\right)$ and was on average $1.34 \mathrm{~W} / \mathrm{cm}^{2}$ [KwarciakKozłowska and Sławik-Dembiczak 2016].

Figure 6 compares the value of organic contaminants determined as COD and TOC in the independent process of ozonation with the process where ozonation effect was intensified by ultrasound waves.

It was found that it is more advantageous to conduct the process of landfill leachate treatment in the combined system (system $\mathrm{O}_{3}+\mathrm{US}$ ), since the level of COD leachate treated after each analysed time of the process was on average by $370 \mathrm{mg} / \mathrm{dm}^{3}$ lower, compared to the liquors which were only subjected to ozonation. After 60 minutes of ozonation and combination of ozonation with sonication, COD in the treated leachate was $1154 \mathrm{mg} / \mathrm{dm}^{3}$ and $865 \mathrm{mg} / \mathrm{dm}^{3}$. In the case of TOC, the landfill leachate treated using the integrated system was characterized by lower value of the index by $126 \mathrm{mg} / \mathrm{dm}^{3}$, on average. Furthermore, the time of the process of leachate
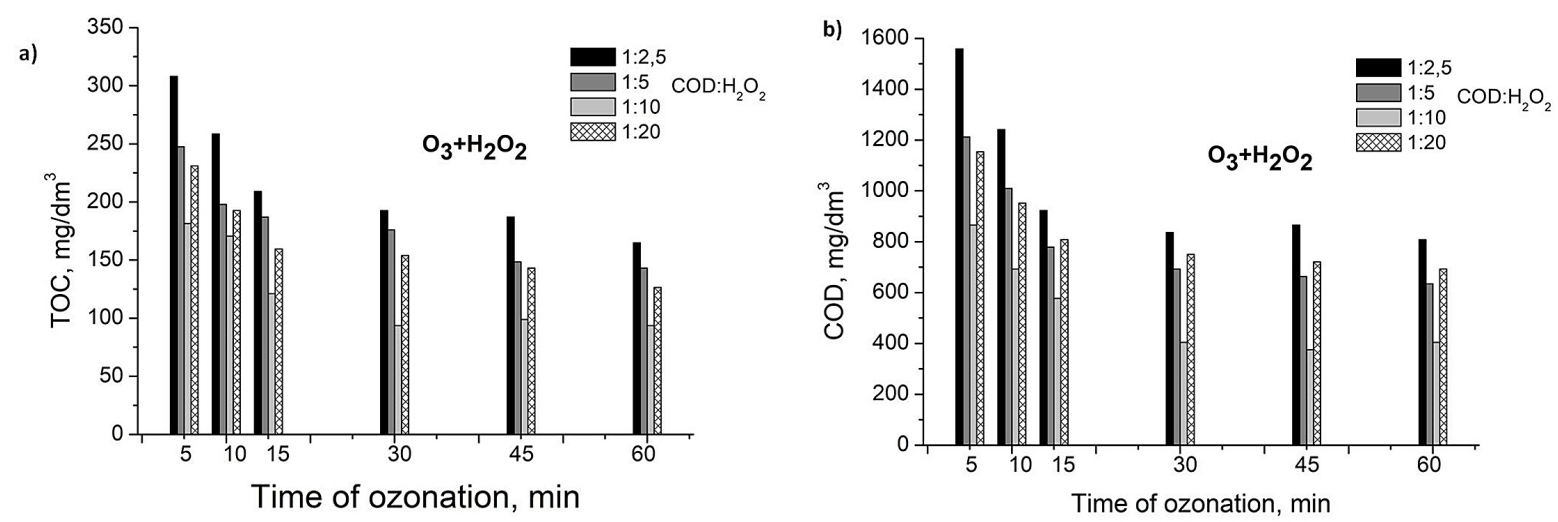

Figure 5. Changes in TOC (a) and COD (b) of the treated leachate depending on the dose of hydrogen peroxide 

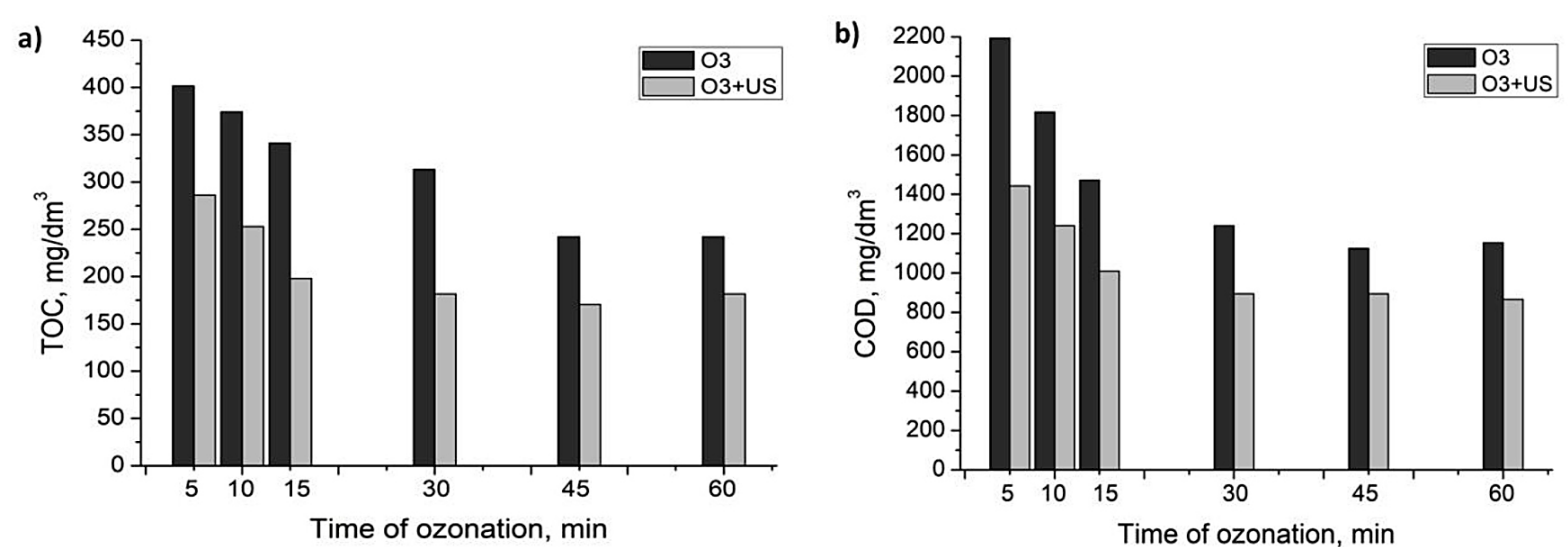

Figure 6. Changes in TOC (a) and COD (b) of the treated leachate in $\mathrm{O}_{3}$ and $\mathrm{O}_{3}+\mathrm{US}$ system

treatment using the $\mathrm{O}_{3}+\mathrm{US}$ method for over 15 minutes (TOC) and 30 minutes (COD) did not impact on the improvement in oxidation of these contaminants.

The last step was the comparison of the results obtained in individual systems of landfill leachate treatment. The values in the tables represent the results obtained in each of the systems under most advantageous conditions (Table 1). It was found that the landfill leachate can be treated in the arrangement that combined ozonation with the addition of hydrogen peroxide (COD: $\mathrm{H}_{2} \mathrm{O}_{2}=1: 10$ ). The value of COD, TOC and BOD in such landfill leachate was lower compared to independent ozonation process by $65 \%, 62 \%$ and $36 \%$, respectively. This landfill leachate is planned to be additionally treated using the low-pressure membrane processes (e.g. ultrafiltration).

\section{CONCLUSIONS}

The results obtained in the study led to the following conclusions:

1. The landfill leachate ozonation process occurs most effectively if the $\mathrm{pH}$ is 8.5 . After 60 minutes of ozonation, the TOC removal rate reached $37 \%\left(346 \mathrm{mg} / \mathrm{dm}^{3}\right)$;
2. It was found that the ozonation of leachate is most effective if its dose is $20 \mathrm{mg} / \mathrm{dm}^{3}$;

3. The most advantageous system of landfill leachate treatment was the the arrangement that combined ozone with hydrogen peroxide (COD: $\mathrm{H}_{2} \mathrm{O}_{2}=1: 10$ ). The value of $\mathrm{COD}$, TOC and BOD in such leachate was lower compared to independent ozonation process by $65 \%$, $62 \%$ and $36 \%$, respectively.

4. Inclusion of the sonication process in ozonation of landfill leachate resulted in a reduction in COD and TOC by $370 \mathrm{mg} / \mathrm{dm}^{3}$ and $126 \mathrm{mg} /$ $\mathrm{dm}^{3}$ compared to ozonation alone.

\section{Acknowledgements}

The study has been funded by BS/ PB-401-301/11

\section{REFERENCES}

1. Amaral-Silva N., Martinsa R.C., Castro-Silva S., Quinta-Ferreira R.M. 2016.Ozonation and perozonation on the biodegradability improvement of a landfill leachate, Journal of Environmental Chemical Engineering 4, 527-533.

2. Barbusiński K. 2013. Advanced oxidation in the treatment of selected industrial wastewater, Pub-

Table 1. Comparison of the quality of landfill leachate treated in the examined combination systems

\begin{tabular}{|c|c|c|c|c|c|}
\hline \multirow{2}{*}{ Indicator } & \multirow{2}{*}{$\begin{array}{c}\text { Raw } \\
\text { Landfill leachate }\end{array}$} & \multicolumn{2}{|c|}{$\begin{array}{c}\text { Purification system applied (characteristics of treated } \\
\text { landfill leachate }- \text { after } 60 \text { min) }\end{array}$} & \multirow{2}{*}{$\begin{array}{c}\text { Permissible } \\
\text { Standards }\end{array}$} \\
\cline { 3 - 5 } & & $\mathrm{O}_{3}$ & $\mathrm{O}_{3}+\mathrm{H}_{2} \mathrm{O}_{2}$ & $\mathrm{O}_{3}+\mathrm{US}$ & \\
\hline $\mathrm{COD}, \mathrm{mg} / \mathrm{dm}^{3}$ & 2885 & 1154 & 404 & 865 & 125 \\
\hline $\mathrm{BOD}, \mathrm{mg} / \mathrm{dm}^{3}$ & 190 & 42 & 27 & 32 & 25 \\
\hline $\mathrm{TOC}, \mathrm{mg} / \mathrm{dm}^{3}$ & 550 & 242 & 93 & 181 & 30 \\
\hline
\end{tabular}

* Regulation of the Ministry of Environmental Protection, Natural Resources and Forestry of 18 November 2014 on the classification of water and conditions the sewage discharged to waters and soil should satisfy. 
lisher of the Silesian University of Technology, Gliwice (in Polish).

3. Bila D.M., Montalvai A.F., Silva A.C., Dezotti M. 2005. Ozonation of a landfill leachate: evaluation of toxicity removal and biodegradability improvement, Journal of Hazardous Materials B117, 235-242.

4. Catalkaya, E.C., Kargi, F. 2007. Color, TOC and AOX removals from pulp mill effluent by advanced oxidation processes: A comparative study, Journal of Hazardous Materials 139, 244-253.

5. Cesaro, A., Naddeo, V., Belgiorno, V. 2013.Wastewater treatment by combination of advanced oxidation processes and conventional biological systems. Journal of Bioremediation \& Biodegradation, 4, 208.

6. Hansen, K.M.S., Spiliotopoulou, A., Chhetri, R.K., Escolà Casas, M., Bester, K., Andersen, H.R. 2016. Ozonation for source treatment of pharmaceuticals in hospital wastewater - Ozone lifetime and required ozone dose, Chemical Engineering Journal 290, 507-514.

7. Kudlek E., Dudziak M., Bohdziewicz J., Kamińska G. 2017. The role of $\mathrm{pH}$ in the decomposition of organic micropollutants during the heterogeneous photocatalysis proces, E3S Web of Conferences $17,00047$.

8. Kurniwana T., Wai-hung L. 2006. Physico-chemical treatment for removal of recalcitrant contaminansts from landfill leachate, Journal of Hazardous Materials 129, 1-3, 80-100.
9. Kwarciak-Kozłowska A., Krzywicka A., GałwaWidera M. 2016. The use of ozonation process in coke wastewater treatment, Rocznik Ochrona Środowiska, 18, 61-73.

10. Kwarciak-Kozłowska A. Sławik-Dembiczak L. 2016. Characterization of the organic fraction of pretreated leachate from old landfill after sonication exposure, Inżynieria i Ochrona Środowiska 19(4), 561-575.

11. Leszczyński J., Tałałaj I., Walery M., Biedka P. 2016. Landfill leachates pretreatment by ozonation, Ecological Engineering, 143-146 (in Polish).

12. Liu, Y., Jiang, J., Ma, J., Yang, Y., Luo, C., Huangfu, X., Guo, Z. 2015. Role of the propagation reactions on the hydroxyl radical formation in ozonation and peroxone (ozone/hydrogen peroxide) processes. Water Research 68, 750-758.

13. Regulation of the Minister of Environment of 18 November 2014 on the conditions to be met when discharging sewage into water or soil, and on the substances particularly harmful to the aquatic environment (in Polish).

14. Suslick, K.S. 1989. The chemical effects of ultrasound. Scientific American 2, 80-86

15. Tizaoui Ch., Bouselmi L., Mansouri L., Ghrabi A. 2007. Landfill leachate treatment with ozone and ozone/hydrogen peroxide systems, Journal of Hazardous Materials 140, 316-324.

16. Zarzycki R. 2002. Advanced oxidation techniques in environmental protection, Łódź, PA Publishing (in Polish). 